\title{
Ammonium removal from aqueous solution by zeolites synthesized from low-calcium and high-calcium fly ashes
}

\author{
Mulan Zhang a, Huayong Zhang a,*, Dan Xu ${ }^{a}$, Lu Han ${ }^{\mathrm{b}}$, Dongxiao Niu ${ }^{\mathrm{c}}$, Luyi Zhang ${ }^{\mathrm{a}}$, \\ Wensi $\mathrm{Wu}^{\text {a }}$, Binghui Tian ${ }^{\mathrm{d}}$ \\ a Research Center for Ecological Engineering and Nonlinear Science, North China Electric Power University, Beijing, 102206, China \\ b Industrial Systems Engineering, University of Regina, 3737 Wascana Parkway, Regina, Saskatchewan, S4S 0A2, Canada \\ ' School of Business and Management, North China Electric Power University, Beijing 102206, China \\ d State Key Laboratory of Environmental Aquatic Chemistry, Research Center for Eco-environmental Sciences, Chinese Academy of Sciences, Beijing 100085, China
}

\section{A R T I C L E I N F O}

\section{Article history:}

Received 7 February 2011

Received in revised form 28 March 2011

Accepted 31 March 2011

Available online 20 April 2011

\section{Keywords:}

Low-calcium fly ash

High-calcium fly ash

Synthesized zeolite

Ammonium removal

Select criteria of raw fly ash

\begin{abstract}
A B S T R A C T
In this study, zeolites are synthesized from low-calcium (LC-Z) and high-calcium (HC-Z) fly ashes, respectively. The changes of mineralogy, morphology, cation exchange capacity (CEC) and specific surface area (SSA) are investigated during the synthesis process. The equilibrium uptake of ammonium on the two synthesized zeolites is compared. The main crystals of LC-Z and HC-Z are identified as faujasite and gismondine, respectively. The CEC and SSA increase significantly following the conversion process. The kinetic studies showed that the adsorption process of ammonium on both LC-Z and HC-Z follows Ho's pseudosecond-order model. Langmuir model agrees better with the equilibrium data for LC-Z, while Freundlich model gives the better fit for HC-Z. The obtained maximum ammonium uptake capacities are $23.8 \mathrm{mg} / \mathrm{g}$ for LC-Z and $3.17 \mathrm{mg} / \mathrm{g}$ for HC-Z in the synthetic solution. LC-Z also exhibits much better performance in ammonium uptake in effluent from a sewage treatment plant than HC-Z. These results indicate that LC-Z is a promising material for ammonium removal whereas $\mathrm{HC}-\mathrm{Z}$ is not. The $\mathrm{Ca}^{2+}$ leaching and the lower zeolite content in HC-Z account for its lower uptake capacity. Thus, the low-calcium fly ash should be chosen preferentially as the raw material of the zeolite synthesis for ammonium removal.
\end{abstract}

(C) 2011 Elsevier B.V. All rights reserved.

\section{Introduction}

The increasing accumulation of nitrogen and phosphorus can lead to eutrophication in lakes, ponds and reservoirs. Eutrophication in turn deteriorates greatly the quality and function of a water body $[1,2]$. The nitrogen and phosphorus removal from wastewater prior to discharge is thus obligatory in many countries nowadays. Nitrogen compounds in aqueous environments are usually found in the form of ammonium [3]. Among various methods available for ammonium removal, ion exchange is proved more useful and economical with the development of low-cost and high-efficient ion exchangers, such as zeolite $[4,5]$.

Fly ash is a waste material generated from an electric power plant. The current annual production of fly ash is about 500 million tonnes, and the world average utilization only amounts to $16 \%$ of the total ash. A substantial amount of fly ash is still disposed of in landfills and/or lagoons at a significant cost to the utilizing companies and thus to the consumers [6]. As a resource utilization approach, extensive research has been carried out to synthesize zeolite using fly ash [7]. The

\footnotetext{
* Corresponding author. Tel./fax.: + 861051971244.

E-mail address: bjecology@gmail.com (H. Zhang).
}

synthesized zeolites are also used to remove the ammonium from wastewater, and the results showed that they are promising ion exchangers for ammonium removal $[8,9]$.

Fly ashes are a complex inorganic and organic mixture, and their chemical properties are influenced to a great extent by the properties of the coal being burned and the techniques used for handling and storage [6]. Various approaches and characteristics have been used to specify fly ashes for their applications. For example, American Association for Testing Materials (ASTM C618) defines two classes of fly ash, Class F fly ash $\left(\mathrm{SiO}_{2}+\mathrm{Al}_{2} \mathrm{O}_{3}+\mathrm{Fe}_{2} \mathrm{O}_{3}>70 \%\right)$ and Class C fly ash $\left(50 \%<\mathrm{SiO}_{2}+\mathrm{Al}_{2} \mathrm{O}_{3}+\mathrm{Fe}_{2} \mathrm{O}_{3}<70 \%\right)[10]$. Fly ash used for cement and concrete in China (GB/T 1596-2005) classifies fly ashes into three groups: low-calcium fly ash $(\mathrm{CaO}<5 \%)$, intermediate-calcium fly ash $(\mathrm{CaO} \approx 15 \%)$, and high-calcium fly ash $(\mathrm{CaO}>15 \%)$. The previous studies also showed that the composition of used fly ash is a determining parameter in the property of the synthesized zeolites [7]. However, the effect of the chemical property of fly ashes on the ammonium removal performance of the synthesized zeolites has received little attention. To obtain the synthesized zeolite with high ammonium uptake capacity, how to select fly ash based on the widely known criterion is still poorly understood.

The present study synthesizes zeolites from two fly ashes with different mineralogical and chemical compositions using alkaline fusion 
followed by hydrothermal method, and investigates the effectiveness of the two synthesized zeolites in removing ammonium from aqueous solution. The mineralogy, morphology, special surface area (SSA) and cation exchange capacity (CEC) of fly ashes and their derived zeolites are analyzed. The adsorption kinetics and equilibrium of ammonium on the two synthesized zeolites are determined, and their performance in ammonium uptake in effluent from a sewage treatment plant is studied. The reason for the difference of the ammonium removal by the two synthesized zeolites is also investigated.

\section{Materials and methods}

\subsection{Zeolite synthesis and characterization}

Fly ashes used in this study were obtained from a power plant located in Yunnan Province, China. A fusion method described previously [8] was adopted for the synthesis of zeolite. The two synthesized zeolites were dried at $100^{\circ} \mathrm{C}$ for $12 \mathrm{~h}$ and then sieved through a 100 mesh $(<150 \mu \mathrm{m})$ for further work. The XRD, SEM, SSA and CEC of the fly ashes and synthesized zeolites were analyzed using the same methods and equipments described in a previous paper [8]. The chemical compositions of the fly ashes and synthesized zeolites were measured using X-ray fluorescence spectrometer (Philips PW2404, Philips Co. Holland), and the results are listed in Table 1.

\subsection{Batch experiments}

The effect of contact time on ammonium removal by the two synthesized zeolites was investigated under different contact times ranging from 0 to $360 \mathrm{~min} .0 .1 \mathrm{~g}$ of the zeolite sample was loaded in a $100 \mathrm{~mL}$ conical flask. Then $50 \mathrm{~mL}$ of the ammonium solution $(100 \mathrm{mg}$ $\mathrm{NH}_{4}^{+}-\mathrm{N} / \mathrm{L}$ ) prepared from anhydrous $\mathrm{NH}_{4} \mathrm{Cl}$ (analytical grade) was added into the flask. The flask was capped and placed in a thermostatic shaker at $25^{\circ} \mathrm{C}$ and $180 \mathrm{rpm}$. The kinetics of ammonium uptake was determined by analyzing the adsorptive uptake of ammonium from aqueous solutions on the synthesized zeolites at different time intervals.

The adsorption isotherm tests were conducted to investigate the ammonium adsorption capacities of the two synthesized zeolites. $25 \mathrm{~mL}$ of solutions in the range of $10-300 \mathrm{mg} \mathrm{NH}_{4}^{+}-\mathrm{N} / \mathrm{L}$ was agitated with $0.1 \mathrm{~g}$ of the zeolite sample. The $\mathrm{pH}$ of the solution was adjusted to 8.0 (optimal pH for the ammonium removal by the synthesized zeolites according to the pre-experiments) by adding $1 \mathrm{~mol} / \mathrm{L}$ of $\mathrm{HCl}$ or $\mathrm{NaOH}$. The $\mathrm{pH}$ of the solution was monitored by a pH meter (DELTA 320). The solutions were shaken in the thermostatic shaker at $25^{\circ} \mathrm{C}$ and $180 \mathrm{rpm}$ for $1.25 \mathrm{~h}$ (sufficient time to reach equilibrium according to the above experiments).

Table 1

Chemical compositions of fly ashes and synthesized zeolites (wt.\%).

\begin{tabular}{|c|c|c|c|c|}
\hline \multirow[t]{2}{*}{ Component } & \multicolumn{4}{|l|}{ Content (\%) } \\
\hline & $\begin{array}{l}\text { Low-calcium } \\
\text { fly ash (LC-F) }\end{array}$ & $\begin{array}{l}\text { High-calcium } \\
\text { fly ash (HC-F) }\end{array}$ & $\begin{array}{l}\text { Zeolite synthesized } \\
\text { from LC-F (LC-Z) }\end{array}$ & $\begin{array}{l}\text { Zeolite synthesized } \\
\text { from HC-F (HC-Z) }\end{array}$ \\
\hline $\mathrm{SiO}_{2}$ & 75.69 & 30.76 & 50.76 & 23.75 \\
\hline $\mathrm{Al}_{2} \mathrm{O}_{3}$ & 6.43 & 14.31 & 15.18 & 9.06 \\
\hline $\mathrm{Fe}_{2} \mathrm{O}_{3}$ & 5.45 & 10.27 & 5.41 & 9.37 \\
\hline $\mathrm{MgO}$ & 0.12 & 3.03 & 0.072 & 2.62 \\
\hline $\mathrm{CaO}$ & 3.31 & 37.55 & 2.09 & 32.51 \\
\hline $\mathrm{Na}_{2} \mathrm{O}$ & 0.51 & 0.15 & 16.24 & 1.02 \\
\hline $\mathrm{K}_{2} \mathrm{O}$ & 0.07 & 1.27 & 0.016 & 0.037 \\
\hline $\mathrm{MnO}$ & 0.41 & 0.042 & 0.38 & 0.033 \\
\hline $\mathrm{TiO}_{2}$ & 1.36 & 0.76 & 0.91 & 0.64 \\
\hline $\mathrm{P}_{2} \mathrm{O}_{5}$ & 0.44 & 0.27 & 0.10 & 0.14 \\
\hline $\mathrm{FeO}$ & 1.3 & 2.15 & 0.25 & 0.45 \\
\hline
\end{tabular}

To evaluate their ammonium removal capacity in real wastewater, $0.05-0.5 \mathrm{~g}$ of the zeolite sample was added into $25 \mathrm{~mL}$ of the effluent from Tengzhou Sewage Treatment Plant in Shandong Province, China in $100 \mathrm{~mL}$ stoppered conical flask. The mixture was then agitated in the thermostatic shaker at $25{ }^{\circ} \mathrm{C}$ and $180 \mathrm{rpm}$ for $1.25 \mathrm{~h}$. During this process, the $\mathrm{pH}$ of the solutions was kept at 8.0 by adding $1 \mathrm{~mol} / \mathrm{L}$ of $\mathrm{HCl}$ or $\mathrm{NaOH}$.

To reflect the effect of co-existing cations in real wastewater on the ammonium removal capacities of the synthesized zeolites, the ammonium concentrations in the real wastewater from Tengzhou Sewage Treatment Plant and distilled water were adjusted to $100 \mathrm{mg} / \mathrm{L}$ using anhydrous $\mathrm{NH}_{4} \mathrm{Cl}$ (analytical grade), respectively. The two obtained solutions $(25 \mathrm{~mL}$ ) were mixed with LC-Z and LC-Z at adsorbent dosage of $2-20 \mathrm{~g} / \mathrm{L}$, respectively. The mixtures were then shaken in the thermostatic shaker at $25^{\circ} \mathrm{C}$ and $180 \mathrm{rpm}$ for $1.25 \mathrm{~h}$, and the $\mathrm{pH}$ of the solutions was kept at 8.0.

To investigate whether there was $\mathrm{Ca}^{2+}$-ion leaching from $\mathrm{Ca}$ component in HC-Z or not, $0.1 \mathrm{~g}$ of HC-Z was added into $25 \mathrm{~mL}$ of distilled water in $100 \mathrm{~mL}$ stoppered conical flasks. The mixture was then stirred in the thermostatic shaker at $25^{\circ} \mathrm{C}$ and $180 \mathrm{rpm}$ for $1.25 \mathrm{~h}$ with equilibrium $\mathrm{pH}$ of 8.0.

To improve its ammonium uptake capacity, HC-Z was washed with distilled water and $\mathrm{NaCl}$ solution, respectively. About $0.5 \mathrm{~g}$ of $\mathrm{HC}-\mathrm{Z}$ was added into $100 \mathrm{~mL}$ of distilled water and $100 \mathrm{~mL} \mathrm{NaCl}$ solution $(1 \mathrm{~mol} / \mathrm{L})$ in $250 \mathrm{~mL}$ stoppered conical flasks, respectively. The $\mathrm{pH}$ of the solutions was adjusted to 8.0. After they were stirred in the thermostatic shaker at $25^{\circ} \mathrm{C}$ and $180 \mathrm{rpm}$ for $1.25 \mathrm{~h}$, the mixtures were then centrifuged. The obtained solid residues were dried at $100{ }^{\circ} \mathrm{C}$ for $12 \mathrm{~h}$, and then sieved through a 100 mesh $(<150 \mu \mathrm{m})$ for further work. To examine their ammonium removal capacity of the two materials obtained, $0.1 \mathrm{~g}$ of the zeolite sample was added into $25 \mathrm{~mL}$ of ammonium solution (50 $\mathrm{mg} \mathrm{NH}_{4}^{+}-\mathrm{N} / \mathrm{L}$ ) in a $100 \mathrm{~mL}$ stoppered conical flask. The solution was stirred in the thermostatic shaker at $25^{\circ} \mathrm{C}$ and $180 \mathrm{rpm}$ for $1.25 \mathrm{~h}$. During the period, the $\mathrm{pH}$ of the solutions was maintained at a defined value (8.0).

After shaking, the suspensions of the abovementioned batch experiments were filtered using $0.45 \mu \mathrm{m}$ cellulose acetate membrane. The concentrations of the ammonium in the resulting supernatants were determined using the Nesslerization method with a unico spectrophotometer (US-2102 PCS). The concentrations of other metal cations $\left(\mathrm{Na}^{+}, \mathrm{K}^{+}, \mathrm{Ca}^{2+}\right.$, and $\left.\mathrm{Mg}^{2+}\right)$ in the supernatants were measured using inductively coupled plasma optical emission spectrometer (ICPOES, Optima 2000, PerkinElmer Co. USA). The amounts of ammonium exchanged by the synthesized zeolites $\left(q_{e}(\mathrm{mg} / \mathrm{g})\right)$ and the ammonium removal percentage were calculated by Eqs. (1) and (2)

Amounts of ammonium exchanged $=\frac{C_{o}-C_{e}}{W} \times V$

Ammonium removal percentage $(\%)=\frac{C_{0}-C_{e}}{C_{0}} \times 100$

where $C_{o}$ and $C_{e}$ are the initial and equilibrium ammonium concentrations of the test solution $(\mathrm{mg} / \mathrm{L})$, respectively, Vis the test solution volume (L), and Wis the amount of adsorbent (g).

All the above experiments were duplicated and the average values were used for analysis.

\section{Results and discussion}

\subsection{Fly ashes}

As it is shown in Table 1, LC-F was characterized by a low CaO content (3.31\%), while HC-F was much higher in abundance in $\mathrm{Ca}$ (37.55\%). On the other hand, the content of $\mathrm{SiO}_{2}$ and $\mathrm{Al}_{2} \mathrm{O}_{3}$ in LC-F was $82.12 \%$, which was higher than that of HC-F (45.07\%). The content of 
Fe in LC-F was 5.45\%, which was much lower than that in HC-F (10.27\%). Based on the ASTM C618, LC-F belongs to Class F, and HC-F belongs to Class $C$, i.e. calcareous fly ash. According to fly ash used for cement and concrete in China (GB/T 1596-2005), LC-F is ascribed to low-calcium fly ash, while HC-F is ascribed to high-calcium fly ash.

The XRD patterns of the fly ashes are shown in Fig. 1. The XRD pattern of LC-F showed a presence of quartz and mullite. On the other hand, in the XRD pattern of HC-F, the major crystalline phases were found to be: anhydrite, quartz and $\mathrm{CaO}$. Morphological analyses of the fly ashes were carried out with SEM, and the results are showed in Fig. 2. As shown in Fig. 2, as for the LC-F, SEM observations showed the presence of micro-particles in the shape of smooth balls (Fig. 2a), while the particles of HC-F exhibited irregular shape (Fig. 2b). The SSA of LC-F and HC-F was identified as 3.147 and $0.894 \mathrm{~m}^{2} / \mathrm{g}$, respectively. The CEC of LC-F and HC-F was determined as 0.033 and $0.045 \mathrm{meq} / \mathrm{g}$, respectively, which was very low and suggested that both LC-F and HC-F have the low capability to hold ammonium.

\subsection{Synthesized zeolites}

Due to the different chemical and mineralogical compositions of the starting fly ashes, the chemical compositions and crystalline phases of the synthesized zeolites were also different (Table 1 and Fig. 3). The various chemical components of the synthesized zeolites decreased slightly compared to those of their corresponding raw fly ashes, but portions of aluminum and sodium oxides in LC-Z increased. In the XRD pattern of LC-Z, the quartz disappeared, but a few mullites were still showing there. The major crystalline phase was identified as zeolite X (faujasite), with small amounts of zeolite A, zeolite P and hydroxysodalite. On the other hand, in the XRD pattern of HC-Z, the major crystalline phase was identified as gismondine. The typical unit cell formula of faujasite is given as $\mathrm{Na}_{20}\left[\mathrm{Al}_{20} \mathrm{Si}_{33} \mathrm{O}_{106}\right] \cdot 70 \mathrm{H}_{2} \mathrm{O}$, thus the mainly exchangeable cation is $\mathrm{Na}^{+}$. At the same time, that of gismondine is given as $\mathrm{Ca}\left[\mathrm{Al}_{2} \mathrm{Si}_{2} \mathrm{O}_{8}\right] \cdot 4.5 \mathrm{H}_{2} \mathrm{O}$, thus the mainly exchangeable cation is $\mathrm{Ca}^{2+}$.

Morphological analyses in Fig. 4 showed that, after alkaline fusion followed by hydrothermal treatment, the spheres of LC-F were deformed, and the smooth surface changed into various crystals shapes (Fig. 4a). The cubic, octahedral and round crystals corresponded to zeolite $\mathrm{A}$, zeolite $\mathrm{X}$ and zeolite $\mathrm{P}$, respectively, which was also confirmed by the XRD data in Fig. 3. As for the HC-F, after fusion, the smooth-surface particles were partly transformed into agglomerations of undefined shape with no observation of crystal formation (Fig. 4b).

The obtained CEC of LC-Z and HC-Z were 2.79 and $0.69 \mathrm{meq} / \mathrm{g}$, respectively (Table 2 ). In comparison with those of their raw fly ashes,

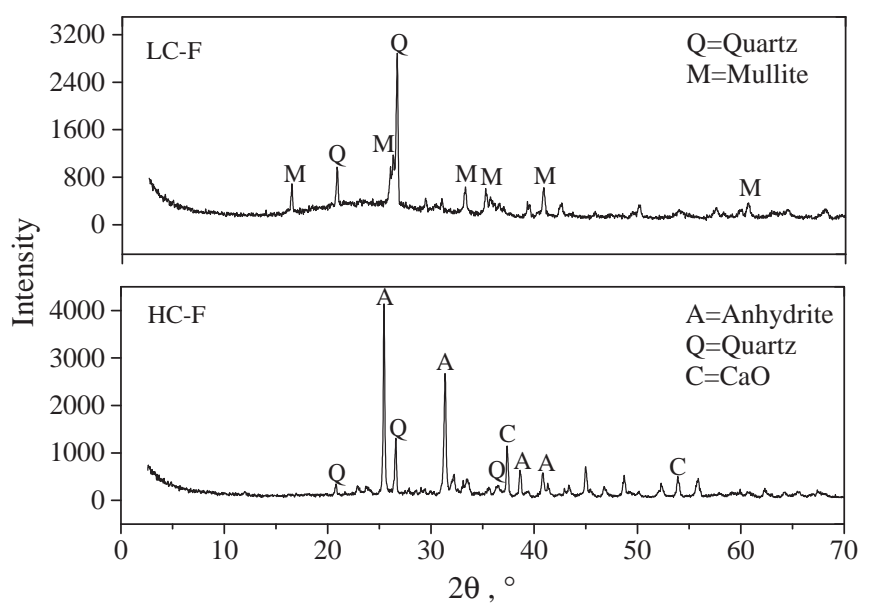

Fig. 1. XRD patterns of fly ashes. the CEC of the synthesized zeolites increased remarkably. After conversation, a significant increase in SSA was also observed, and the SSA of LC-Z and HC-Z were determined as 27.015 and $45.511 \mathrm{~m}^{2} / \mathrm{g}$, respectively. The increase of CEC and SSA following the synthesis process may be due to the formation of zeolite with rough surface structure after alkaline fusion followed by hydrothermal treatment.

\subsection{Effect of contact time on the ammonium uptake by $L C-Z$ and HC-Z}

Before performing the batch uptake equilibrium experiments, it is necessary to determine the contact time required for adsorption equilibrium. Fig. 5 shows the ammonium uptake by LC-Z and HC-Z as a function of contact time. The results reveal that the removal of ammonium by the two synthesized zeolites was a very rapid process. For LC-Z, 86\% of the final ammonium uptake was complete within the first 10 min of the reaction. Sixty minutes after initial reaction, uptake nearly reached equilibrium, and the uptake amount of ammonium became almost stable. For HC-Z, the ammonium uptake also increased rapidly with the contact time, and the final ammonium uptake were almost captured in HC-Z within initial $60 \mathrm{~min}$. 90\% equilibrium is reached in $20 \mathrm{~min}$ for LC-Z and $60 \mathrm{~min}$ for HC-Z, respectively. The fast ammonium removal rate at the initial stage of uptake was due to the fact that, initially, all adsorbent sites were vacant and the solute concentration gradient was high. Previous studies also found that ammonium uptake by zeolite is a fast process, and uptake equilibrium is achieved at even shorter time periods of 10 and $15 \mathrm{~min}$ [5]. The reason for equilibrium time discrepancies in different studies may be specific to the materials used, the experimental conditions or a combination of the two. To reach uptake equilibrium, the contact time was fixed at $1.25 \mathrm{~h}$ for the following batch experiments.

\subsection{Adsorption kinetics}

The adsorption process of porous adsorbents is controlled by three steps: liquid film diffusion, intraparticle diffusion and chemical reaction. The study of uptake kinetics is significant as it provides valuable insights into the reaction pathway and describes the solute uptake rate which in turn controls the residence time of adsorbate uptake at the solid-solution interface. To investigate the exchange process of ammonium by the two synthesized zeolites, Lagergren first-order and Ho's pseudo-second-order kinetic models were employed to test the experimental data [11,12]. The Lagergren firstorder and Ho's pseudo-second-order models are respectively described in the following equations:

$$
\ln \left(q_{e}-q_{t}\right)=\ln q_{e}-k_{1} t
$$

$\frac{t}{q_{t}}=\frac{1}{k_{2} q_{e}^{2}}+\frac{t}{q_{e}}$

where $q_{e}$ and $q_{t}$ are the amounts of adsorbate adsorbed on the adsorbents $\left(\mathrm{mg} \cdot \mathrm{g}^{-1}\right)$ at equilibrium and at time $t$, respectively. The values $k_{1}\left(\mathrm{~min}^{-1}\right)$ and $k_{2}\left(\mathrm{~g} \cdot \mathrm{mg}^{-1} \cdot \mathrm{min}^{-1}\right)$ are the rate constants of first- and second-order models, respectively.

The kinetic data were linearized using the Lagergren first-order and Ho's pseudo-second-order models, and plotted between $\ln \left(\mathrm{q}_{\mathrm{e}}-\mathrm{q}_{\mathrm{t}}\right)$ versus $t$ and $t / q_{e}$ versus $t$, respectively. The constants were calculated from the slope and the intercept of the plots, and are given in Table 3. The results show that, for both LC-Z and HC-Z, the coefficients of determination $\left(\mathrm{R}^{2}=0.9997,0.9687\right)$ for Ho's pseudo-second-order model were much higher than those obtained using the Lagergren first-order model $\left(\mathrm{R}^{2}=0.25\right.$ and 0.49 ). Thus, the Ho's pseudo-secondorder model explains the kinetic processes better. The predicted values of qe using the Ho's pseudo-second-order model were $15.92 \mathrm{mg} / \mathrm{g}$ for LC-Z and $2.81 \mathrm{mg} / \mathrm{g}$ for HC-Z, respectively, which were very close to experimental data ( $15.95 \mathrm{mg} / \mathrm{g}$ for LC-Z, and $2.41 \mathrm{mg} / \mathrm{g}$ for HC-Z). The 
(a) LC-F
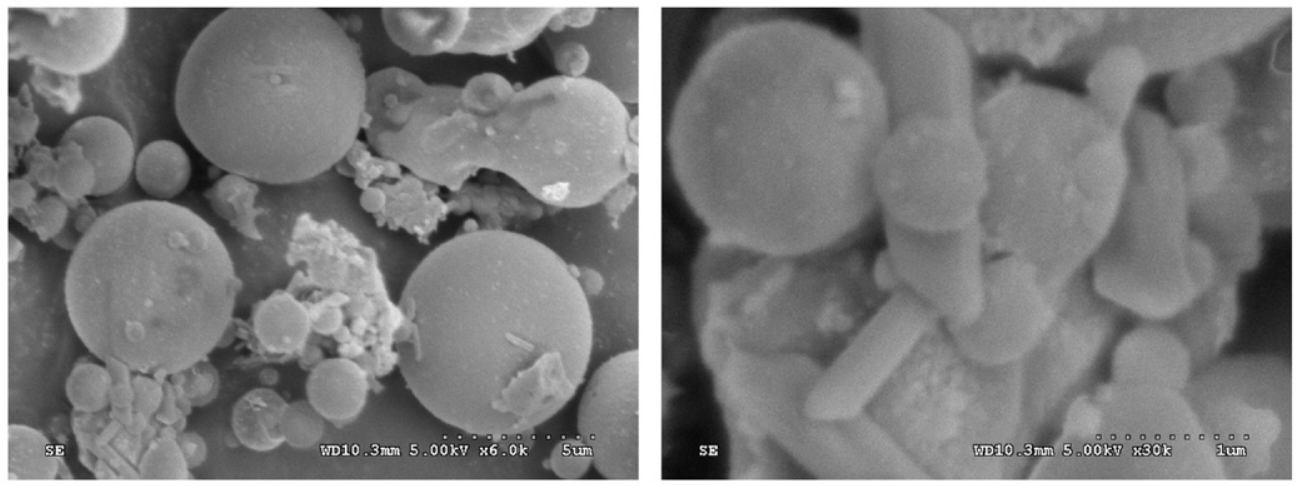

(b) HC-F
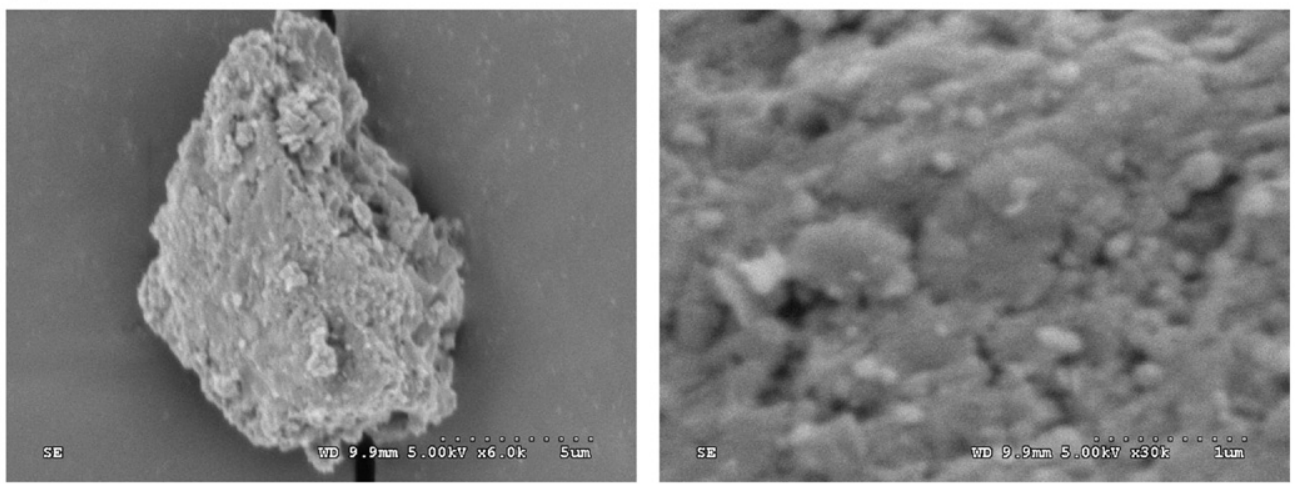

Fig. 2. SEM images of fly ashes.

obtained rate constants, $\mathrm{K}_{2}$, were $3.63 \times 10^{-2} \mathrm{~g} \cdot \mathrm{mg}^{-1} \cdot \mathrm{min}^{-1}$ for LC-Z and $0.72 \times 10^{-2} \mathrm{~g} \cdot \mathrm{mg}^{-1} \cdot \mathrm{min}^{-1}$ for HC-Z, respectively.

\subsection{Adsorption isotherm}

Adsorption isotherms are important for revealing the adsorption mechanism for the interaction of adsorbate with the adsorbent. The dynamic adsorptive separation of solute from solution onto an adsorbent depends upon a good description of the equilibrium separation between the two phases. Many models have been proposed to describe the adsorption process, in which Langmuir and Freundlich isotherm models are most commonly used $[13,14]$.

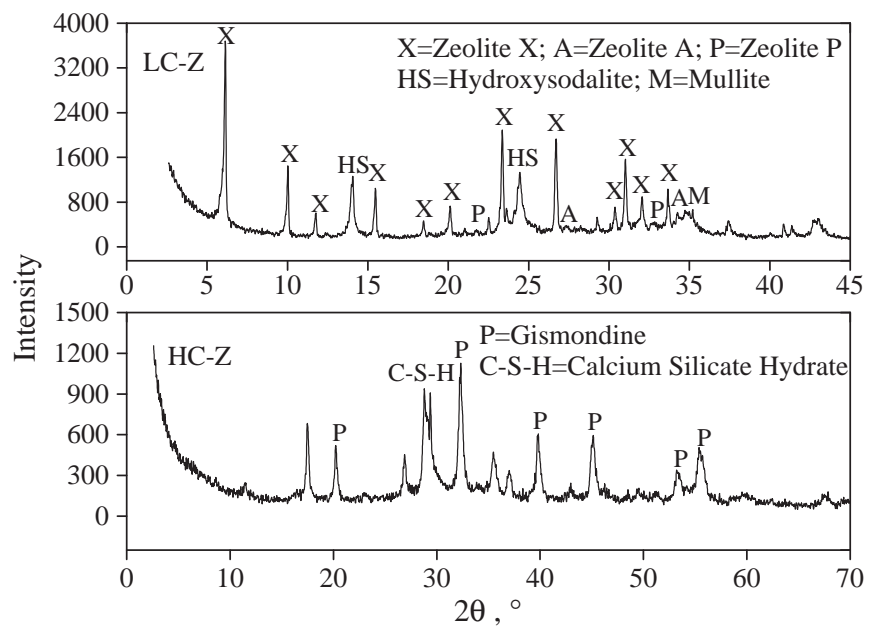

Fig. 3. XRD patterns of synthesized zeolites.

\subsubsection{Langmuir isotherm}

The Langmuir isotherm assumes that adsorption happens at specific homogeneous sites within the adsorbent, and there is no interaction between the adsorbate molecules. The saturated monolayer isotherm can be represented as:

$\frac{C_{e}}{q_{e}}=\frac{1}{b Q_{m}}+\left(\frac{1}{Q_{m}}\right) C_{e}$

where $b$ is a constant related to the affinity of the binding sites and energy of the adsorption $(\mathrm{L} / \mathrm{mg}), Q_{\mathrm{m}}$ is the maximum monolayer adsorption capacity, $Q_{e}$ is the amount adsorbed on a unit mass of the adsorbent $(\mathrm{mg} / \mathrm{g})$, and $C_{\mathrm{e}}$ is the equilibrium concentration $(\mathrm{mg} / \mathrm{L})$.

The essential features of the Langmuir isotherm can be expressed in terms of dimensionless constant separation factor, $R_{\mathrm{L}}$, given by $R_{L}=\frac{1}{1+b C_{0}}$ [15]. A value of $R_{\mathrm{L}}$ between 0 and 1 represents favorable adsorption, while $R_{\mathrm{L}}>1$ represents unfavorable adsorption, $R_{\mathrm{L}}=1$ represents linear adsorption, and $R_{\mathrm{L}}=0$ represents irreversible adsorption.

The adsorption equilibrium data were plotted between $\mathrm{C}_{\mathrm{e}} / \mathrm{q}_{\mathrm{e}}$ versus $C_{e}$ for construction of the Langmuir isotherm. The values of $Q_{m}$ and $\mathrm{b}$ were calculated from the slope and the intercept of the plots, respectively, and are listed in Table 4. For LC-Z, the Langmuir constant $\mathrm{Q}_{\mathrm{m}}$ was obtained as $28.65 \mathrm{mg} / \mathrm{g}$, which was higher than the experimental result $(23.8 \mathrm{mg} / \mathrm{g})$. The constant $\mathrm{b}$ was found to be $0.0212 \mathrm{~L} / \mathrm{mg}$. The low value of $\mathrm{b}$ indicates the high affinity between ammonium and LC-Z. The obtained value of the coefficient of determination was 0.9866 . The dimensionless parameter $\mathrm{R}_{\mathrm{L}}$ was in the range of 0.14 and $0.83\left(0<R_{L}<1\right)$, suggesting that the uptake process was a favorable one. For HC-Z, the Langmuir constants $\mathrm{Q}_{\mathrm{m}}$ and b were obtained as $6.12 \mathrm{mg} / \mathrm{g}$ and $0.00407 \mathrm{~L} / \mathrm{mg}$, respectively. The obtained value of coefficient of determination was 0.599. The dimensionless parameter $R_{L}$ was in the range of 0.45 and 0.96 
(a) LC-Z
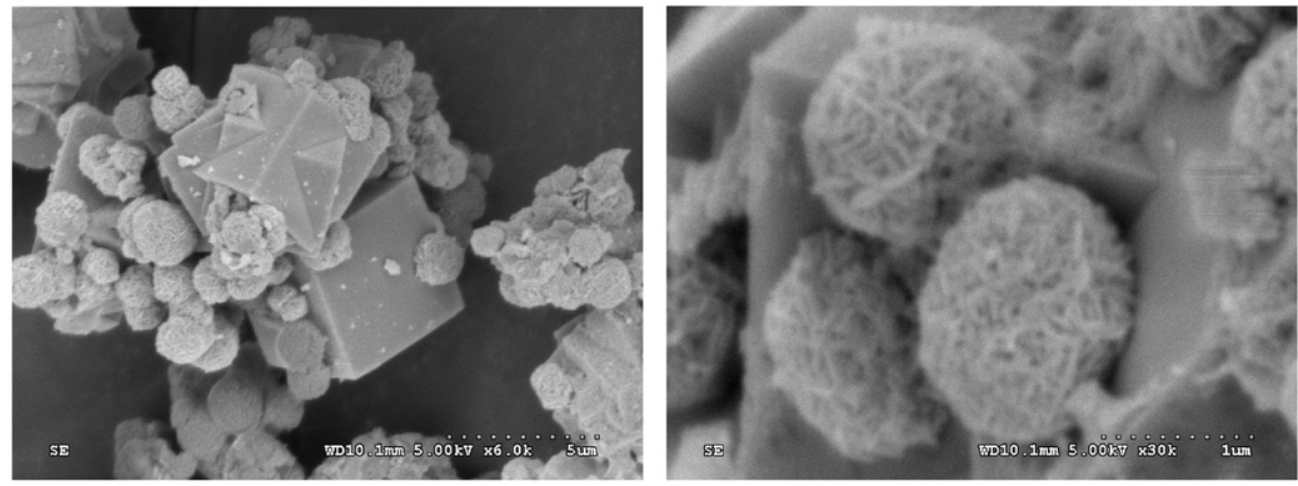

(b) HC-Z
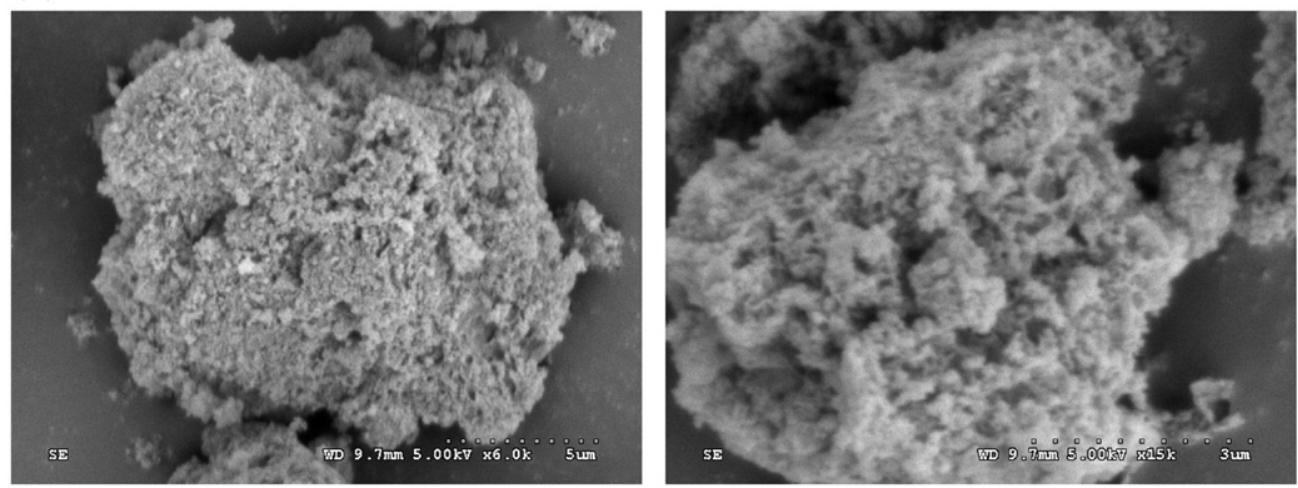

Fig. 4. SEM images of synthesized zeolites.

$\left(0<\mathrm{R}_{\mathrm{L}}<1\right)$, which indicated that the uptake process was also a favorable one for HC-Z.

\subsubsection{Freundlich isotherm}

The Freundlich isotherm is an empirical equation describing adsorption onto a heterogeneous surface. It is expressed as:

$\log q_{e}=\log K_{f}+n_{f} \log C_{e}$

where $K_{\mathrm{f}}$ and $\mathrm{n}_{\mathrm{f}}$ are the Freundlich constants related to the adsorption capacity and adsorption intensity of the sorbent, respectively. $\mathrm{C}_{\mathrm{e}}$ and $\mathrm{q}_{\mathrm{e}}$ are similar to those in the Langmuir isotherm model. The $\mathrm{n}_{\mathrm{f}}$ should be in the range of $0.1-1$ for beneficial adsorption.

The Freundlich constants were obtained by plotting the graph between $\log \mathrm{q}_{\mathrm{e}}$ versus $\log \mathrm{C}_{\mathrm{e}}$, and are listed in Table 4. For LC-Z, the obtained $K_{\mathrm{f}}$ was 1.303 . The $\mathrm{n}_{\mathrm{f}}$ was 0.5797 and in the range of beneficial adsorption. Combining the result obtained using the Langmuir isotherm model together, the results confirm the beneficial uptake process for ammonium using LC-Z as an adsorbent. The coefficient of determination $\left(R^{2}=0.9753\right)$ was lower than that of the Langmuir isotherm model, indicating that the Langmuir isotherm model yields a much better fit with the experimental data compared with the Freundlich model. This suggests that the homogeneous uptake happened for ammonium by LC-Z. For HC-Z, the constant $\mathrm{K}_{\mathrm{f}}$ was obtained as 0.047 . The obtained value of $n_{f}$ was 0.7751 , which was also in the range of beneficial adsorption. The results obtained by both

Table 2

Basic parameters of the fly ashes and synthesized zeolites.

\begin{tabular}{lllcc}
\hline Parameters & LC-F & HC-F & LC-Z & HC-Z \\
\hline CEC $(\mathrm{meq} / \mathrm{g})$ & 0.033 & 0.045 & 2.79 & 0.69 \\
SSA $\left(\mathrm{m}^{2} / \mathrm{g}\right)$ & 3.147 & 0.894 & 27.015 & 45.511 \\
\hline
\end{tabular}

Langmuir and Freundlich isotherm models indicate the beneficial uptake process of ammonium by HC-Z. The obtained coefficient of determination $\left(R^{2}=0.9151\right)$ was much higher than that of the Langmuir isotherm model, indicating that the Freundlich isotherm model provides a better fit for the ammonium uptake process by HC-Z. This suggests that, contrary to LC- $Z$, the heterogeneous uptake takes place for ammonium on HC-Z.

Different results about the suitable adsorption isotherm for various zeolites were also obtained in previous studies [3,5,16-18]. The equilibrium patterns of ammonium on natural Turkish clinoptilolite, MesoLite and rice husk ash-synthesized zeolite Y fit well with the Langmuir isotherm $[5,16,17]$. However, the Freundlich model was better than Langmuir to represent equilibrium data of ammonium exchange by clinoptilolite and microwave-treated zeolite $[3,18]$. These results confirm that different zeolites have different characters and thus different equilibrium patterns.

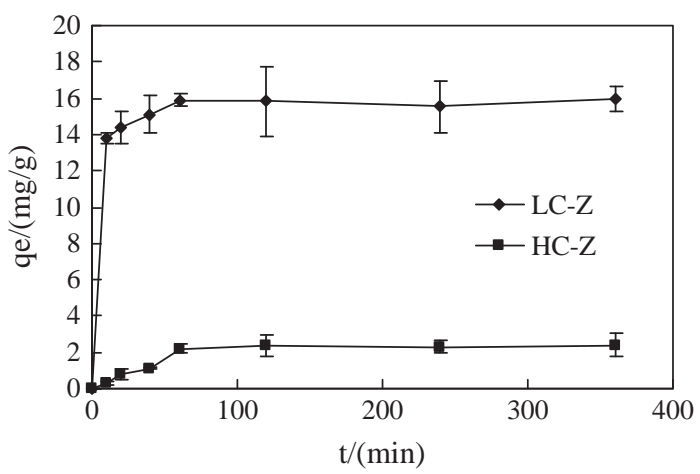

Fig. 5. Effect of contact time on ammonium removal by the synthesized zeolites $\left(\mathrm{C}_{0}=100 \mathrm{mg} \mathrm{NH}{ }^{+}-\mathrm{N} / \mathrm{L} ;\right.$ adsorbent dose $\left.=2 \mathrm{~g} / \mathrm{L} ; \mathrm{T}=25^{\circ} \mathrm{C}\right)$. 
Table 3

Rate constants and correlation coefficients for the studied kinetic models (adsorbent dose $\left.=2 \mathrm{~g} / \mathrm{L} ; \mathrm{C}_{0}=100 \mathrm{mg} / \mathrm{L} ; \mathrm{T}=25^{\circ} \mathrm{C}\right)$.

\begin{tabular}{llllllll}
\hline \multirow{2}{*}{ Adsorbent } & \multicolumn{2}{l}{ Lagergren first-order model } & & \multicolumn{3}{c}{ Ho's pseudo-second-order model } \\
\cline { 2 - 3 } & $\mathrm{q}_{\mathrm{e}} /(\mathrm{mg} / \mathrm{g})$ & $\mathrm{K}_{1}$ & $\mathrm{R}^{2}$ & & $\mathrm{q}_{\mathrm{e}} /(\mathrm{mg} / \mathrm{g})$ & $\mathrm{K}_{2}$ & $\mathrm{R}^{2}$ \\
\hline $\mathrm{LC}-\mathrm{Z}$ & 1.62 & 0.0112 & 0.25 & & 15.92 & 0.0363 & 0.9997 \\
$\mathrm{HC}-\mathrm{Z}$ & 1.37 & 0.0168 & 0.49 & 2.81 & 0.0072 & 0.9687 \\
\hline
\end{tabular}

Under the experimental conditions studied, the obtained maximum ammonium uptake capacities of LC-Z and HC-Z were 23.8 and $3.17 \mathrm{mg} / \mathrm{g}$, respectively. In comparison with their CECs, the CEC utilizing ratio was $60.9 \%$ for LC-Z and $32.8 \%$ for HC-Z, respectively. LC-Z has higher CEC percentage utilized and much higher ammonium uptake capacity than HC-Z. Comparison with their SSA, LC-Z with lower SSA had a better performance in ammonium removal. This also confirms that the main mechanism of ammonium removal by the synthesized zeolites was ion exchange, and not physical adsorption.

A comparison of the ammonium uptake capacities by various zeolites is showed in Table 5. The comparison is somewhat difficult as they require the experiments to be carried out under the same experimental conditions. As shown in Table 5, it is generally true to say that LC-Z had strong ability in ammonium uptake. However, the ammonium removal capacity of HC-Z was lower than the most reported results in the literature.

3.6. The performance of $L C-Z$ and $H C-Z$ in ammonium uptake in effluent from sewage treatment plant

Real municipal and industrial wastewaters are complex solutions. Other cations, such as $\mathrm{K}^{+}, \mathrm{Na}^{+}, \mathrm{Ca}^{2+}$ and $\mathrm{Mg}^{2+}$, generally coexist with the ammonium ion, which can compete for exchange sites and reduce the uptake of ammonium. In order to know the actual capacity of the synthesized zeolites for the ammonium removal, the performance of the synthesized zeolites in ammonium uptake in effluent from Tengzhou Sewage Treatment Plant was investigated. The ammonium concentrations in equilibrium after treatment by LC-Z and HC-Z are given in Fig. 6. The concentrations of $\mathrm{Na}^{+}, \mathrm{K}^{+}, \mathrm{Ca}^{2+}$ and $\mathrm{Mg}^{2+}$ in the effluent were determined as $84.05 \mathrm{mg} / \mathrm{L}, 19.15 \mathrm{mg} / \mathrm{L}, 70.54 \mathrm{mg} / \mathrm{L}$ and $28.08 \mathrm{mg} / \mathrm{L}$, respectively. The ammonium concentration in the effluent was determined as $7.3 \mathrm{mg} / \mathrm{L}$, which belongs to class IB (ammonium concentration $\leq 8.0 \mathrm{mg} / \mathrm{L}$ ) effluent according to the ammonium discharge standard of pollutants for municipal wastewater treatment plant (GB 18918-2002) in China. The results in Fig. 6 show that the ammonium concentrations in equilibrium after treatment decreased with the increase of zeolite dosage from $2 \mathrm{~g} / \mathrm{L}$ to $20 \mathrm{~g} / \mathrm{L}$. For LC-Z, when its amounts added were $12 \mathrm{~g} / \mathrm{L}$ and $20 \mathrm{~g} / \mathrm{L}$, the ammonium concentrations in effluent met basically the Surface Water Environment Quality Standard in China (GB3838-2002) V (ammonium concentration $\leq 2.0 \mathrm{mg} / \mathrm{L}$ ) and IV (ammonium concentration $\leq 1.5 \mathrm{mg} / \mathrm{L}$ ) after treatment, respectively. On the other hand, HC-Z exhibited a lower ability to uptake ammonium in the effluent. At the HC-Z dosage of $20 \mathrm{~g} / \mathrm{L}$, the ammonium concentrations after treatment decreased from 7.3 to 6.36 , and the treated effluent still belonged to the class IB level according to GB 18918-2002.

\section{Table 4}

Isotherm constants and regression data of Langmuir and Freundlich isotherm models for uptake of ammonium on $\mathrm{LC}-\mathrm{Z}$ and $\mathrm{HC}-\mathrm{Z}$ (adsorbent dose $=4 \mathrm{~g} / \mathrm{L} ; \mathrm{pH}=8.0$; $\left.\mathrm{T}=25^{\circ} \mathrm{C}\right)$.

\begin{tabular}{lllllllll}
\hline Adsorbent & Langmuir & & & & Freundlich \\
\cline { 2 - 3 } \cline { 7 - 8 } & $\mathrm{Q}_{\mathrm{m}}(\mathrm{mg} / \mathrm{g})$ & $\mathrm{b}(\mathrm{L} / \mathrm{mg})$ & $\mathrm{R}^{2}$ & & $\mathrm{~K}_{\mathrm{F}}(\mathrm{mg} / \mathrm{g})$ & $\mathrm{n}_{\mathrm{F}}$ & $\mathrm{R}^{2}$ \\
\hline $\mathrm{LC}-\mathrm{Z}$ & 28.65 & 0.0212 & 0.9866 & & 1.303 & 0.5797 & 0.9753 \\
$\mathrm{HC}-\mathrm{Z}$ & 6.12 & 0.00407 & 0.599 & & 0.047 & 0.7751 & 0.9151 \\
\hline
\end{tabular}

According to the above results, when the adsorbent dosage was $4 \mathrm{~g} / \mathrm{L}$, the ammonium removal efficiencies in the real wastewater were $51.1 \%$ for $\mathrm{LC}-\mathrm{Z}$ and $4.79 \%$ for HC-Z. At the same experimental conditions, the ammonium removal efficiencies obtained in the synthetic solution with the initial ammonium concentration of $10 \mathrm{mg} / \mathrm{L}$ were $74.6 \%$ for $\mathrm{LC}-\mathrm{Z}$ and $8.5 \%$ for HC-Z in the adsorption isotherm tests ( 3.5 section). Compared with those, the ammonium removal efficiencies in the real wastewater decreased by $23.5 \%$ for LC-Z and 3.71\% for HC-Z. If the initial ammonium concentration in the real wastewater is $10 \mathrm{mg} / \mathrm{L}$, the decrease will be bigger. These results indicate that the co-existing cations in real wastewater indeed reduced the ammonium removal capacity of LC-Z and HC-Z, especially for LC-Z. As the ammonium concentration in municipal and industrial wastewater varies usually and may be up to $100 \mathrm{mg} / \mathrm{L}$, the ammonium concentrations in both real wastewater and distilled water were adjusted to $100 \mathrm{mg} / \mathrm{L}$ using anhydrous $\mathrm{NH}_{4} \mathrm{Cl}$, and the ammonium removal efficiencies of $\mathrm{LC}-\mathrm{Z}$ and $\mathrm{HC}-\mathrm{Z}$ were investigated in the two obtained solutions with the high ammonium concentration, respectively. The results in Fig. 7 show that there was also the decrease in the ammonium removal efficiency of LC-Z and HC-Z in the real wastewater compared with those obtained in the synthetic solution at the same adsorbent dosage. Although the decrease of LC-Z (4.97\%$15.04 \%)$ was higher than that of HC-Z (0.68\%-3.99\%), LC-Z still had much higher ammonium removal efficiency than HC-Z in both real wastewater and synthetic solution. At the adsorbent dosage of $4 \mathrm{~g} / \mathrm{L}$, the ammonium removal efficiency in the real wastewater decreased by $10.49 \%$ for LC-Z and $2.92 \%$ for HC-Z compared with those in the synthetic solution. In comparison with those obtained at low ammonium concentration $(7.3 \mathrm{mg} / \mathrm{L})$, the decrease in the ammonium removal efficiency of LC-Z and HC-Z at high ammonium concentration $(100 \mathrm{mg} / \mathrm{L})$ decreased, indicating that the effect of co-existing cations in the real wastewater on the ammonium removal capacity of LC-Z and HC-Z decreased with the increase of the initial ammonium concentration. The results in Fig. 7 also show that the decrease of the ammonium removal efficiency of LC-Z in real wastewater compared to that in synthetic solution decreased (from $15.04 \%$ to $4.97 \%$ ) with the increase of the adsorbent dosage. This indicates that the slight decrease in the ammonium removal efficiency of LC- $Z$ in real wastewater can be offset through increasing properly the adsorbent dosage and by not exerting a significant influence on its practical application in municipal and industrial wastewater.

These results, which were obtained by the batch experiments using both the synthetic ammonium solution and real wastewater, show that the two zeolites synthesized using the same synthesis procedure exhibit distinct difference in ammonium uptake capacities. LC-Z has high ammonium uptake capacity and is a promising material for removing ammonium from wastewater, whereas the HC-Z has a poor performance in ammonium removal. This indicates that the mineralogical and chemical compositions of the fly ash significantly affect the property of its derived zeolite.

\subsection{Reason for the difference in the ammonium uptake capacity of $L C-Z$ and $\mathrm{HC}-\mathrm{Z}$}

It is very important to know the reason causing the different ammonium uptake capacities of LC-Z and HC-Z, as that can provide the starting fly ash selection criteria of the zeolite synthesis for ammonium removal. To investigate the difference, after the completion of the ammonium exchange by the LC-Z and HC-Z in the synthetic ammonium solutions, the concentrations of $\mathrm{Na}^{+}, \mathrm{K}^{+}, \mathrm{Ca}^{2+}$ and $\mathrm{Mg}^{2+}$ transferred from the zeolites to the solutions were measured, and the results are given in Table 6 . In the solution treated by LC-Z, the main cation was $\mathrm{Na}^{+}$whose concentration was $121.33 \mathrm{mg} / \mathrm{L}$. The concentration of $\mathrm{K}^{+}$was $1.90 \mathrm{mg} / \mathrm{L}$. Those of $\mathrm{Ca}^{2+}$ and $\mathrm{Mg}^{2+}$ were lower than the detection limit. Both our and other studies showed that ion exchange is the main mechanism of the ammonium adsorption onto 
Table 5

Exchange capacities of ammonium by various natural and synthesized zeolite.

\begin{tabular}{|c|c|c|c|}
\hline Adsorbent & Experimental conditions & Exchange capacity $(\mathrm{mg} / \mathrm{g})\left(\mathrm{C}_{\mathrm{e}}=100 \mathrm{mg} \mathrm{N} / \mathrm{L}\right)$ & Reference \\
\hline LC-Z & $\mathrm{pH}=8.0$, adsorbent dosage $=4 \mathrm{~g} / \mathrm{L}, \mathrm{T}=25^{\circ} \mathrm{C}$ & 18.19 & This work \\
\hline $\mathrm{HC}-\mathrm{Z}$ & $\mathrm{pH}=8.0$, adsorbent dosage $=4 \mathrm{~g} / \mathrm{L}, \mathrm{T}=25^{\circ} \mathrm{C}$ & 2.54 & This work \\
\hline $\begin{array}{l}\text { Zeolite synthesized from fly } \\
\text { ash using hydrothermal method }\end{array}$ & $\begin{array}{l}\text { Intial } \mathrm{pH}=7.7 \text {, adsorbent dosage }=1.42 \mathrm{~g} / \mathrm{L} \text {, } \\
\mathrm{T}=\text { room temperature }\left(\text { about } 25^{\circ} \mathrm{C}\right)\end{array}$ & $7.02\left(\mathrm{C}_{\mathrm{e}}=22.4 \mathrm{mg} / \mathrm{L}\right)$ & [9] \\
\hline $\begin{array}{l}\text { Zeolite synthesized from fly } \\
\text { ash using hydrothermal method }\end{array}$ & $\begin{array}{l}\text { Intial } \mathrm{pH}=4.98-6.02 \text {, adsorbent dosage }=10 \mathrm{~g} / \mathrm{L} \text {, } \\
\mathrm{T}=\text { room temperature (about } 18-22^{\circ} \mathrm{C} \text { ) }\end{array}$ & $0-14.4$ & {$[21]$} \\
\hline Natural Turkish clinoptilolite & Adsorbent dosage $=10 \mathrm{~g} / \mathrm{L}, \mathrm{T}=25,40,55^{\circ} \mathrm{C}$ & $6.62\left(25^{\circ} \mathrm{C}\right), 5.50\left(40^{\circ} \mathrm{C}\right)$ and $4.01\left(55^{\circ} \mathrm{C}\right)$ & [5] \\
\hline Natural Chinese clinoptilolite & $\mathrm{pH}=6$, adsorbent dosage $=50 \mathrm{~g} / \mathrm{L}, \mathrm{T}=20^{\circ} \mathrm{C}$ & 4.24 & {$[22]$} \\
\hline Bigadic zeolite (Turkey) & $\mathrm{pH}<7.5$, adsorbent dosage $=1 \mathrm{~g} / \mathrm{L}$ & 4.6 (raw), 9.7(conditioned) & [23] \\
\hline New Zealand mordenite and clinoptilolite & $\mathrm{pH}<7.5$, adsorbent dosage $=10 \mathrm{~g} / \mathrm{L}$ & 6.54 (clinoptilolite), 12.01 (mordenite) & [24] \\
\hline Natural Chinese clinoptilolite & $\mathrm{pH}<6$, adsorbent dosage $=5 \mathrm{~g} / \mathrm{L}$ & 4.9 & [25] \\
\hline Chabazite & Adsorbent dosage $=10 \mathrm{~g} / \mathrm{L}, \mathrm{T}=20^{\circ} \mathrm{C}$ & 2.94 & [26] \\
\hline
\end{tabular}

the zeolitic materials $[3,7,8]$. This indicates that ammonium uptake occurs mainly by ion exchange with $\mathrm{Na}^{+}$-ions in $\mathrm{LC}-\mathrm{Z}$ in this study. The chemical compositions and typical unit cell formula mentioned above also showed that the exchangeable cation of $\mathrm{LC}-\mathrm{Z}$ was $\mathrm{Na}^{+}$ions. This confirms that the adsorption mechanism of ammonium on LC-Z is ion exchange between the exchangeable $\mathrm{Na}^{+}$ions in $\mathrm{LC}-\mathrm{Z}$ and the $\mathrm{NH}_{4}^{+}$ions in aqueous solution. The ion-exchange reaction of ammonium and LC-Z is represented as:

Zeolite $-\mathrm{Na}^{+}+\mathrm{NH}_{4}^{+} \leftrightarrow \mathrm{Na}^{+}+$Zeolite $-\mathrm{NH}_{4}^{+}$

On the other hand, in the solution treated by the HC-Z, the main cation was $\mathrm{Ca}^{2+}$ whose concentration was $126.07 \mathrm{mg} / \mathrm{L}$. The following cations were $\mathrm{K}^{+}, \mathrm{Na}^{+}$and $\mathrm{Mg}^{2+}$, and the concentrations of which were $26.8 \mathrm{mg} / \mathrm{L}, 16.51 \mathrm{mg} / \mathrm{L}$ and $1.57 \mathrm{mg} / \mathrm{L}$, respectively. It suggests that the ammonium is mainly removed by ion exchange with $\mathrm{Ca}^{2+}$ ions in the solution treated by HC-Z. Thus, the concentration in meq/L of $\mathrm{Ca}^{2+}$ released should be equal to that of the adsorbed ammonium. Since the adsorbed ammonium concentration was determined as $0.27 \mathrm{meq} / \mathrm{L}$, the released $\mathrm{Ca}^{2+}$ concentration was then $0.27 \mathrm{meq} / \mathrm{L}$ or $5.4 \mathrm{mg} / \mathrm{L}$. Therefore, the amount of $\mathrm{Ca}^{2+}$ for ion exchange with ammonium only contributes a small part of $\mathrm{Ca}^{2+}$ present in the solution treated by HC-Z. The previous studies showed that $\mathrm{Ca}^{2+}$-ion can be released by leaching of Ca-compounds present in zeolitic materials when the amount of $\mathrm{CaO}$ was above $10 \%[9]$. The $\mathrm{CaO}$ content in HC-Z was determined as $32.51 \%$ (Table 1 ), thus HC-Z was washed with distilled water to investigate whether there was $\mathrm{Ca}^{2+}$-ion leaching from Ca-component in HC-Z or not. In the solution which was obtained by agitating $\mathrm{HC}-\mathrm{Z}$ with distilled water, the $\mathrm{Ca}^{2+}$ concentration was up to $92.65 \mathrm{mg} / \mathrm{L}$, indicating that there is indeed

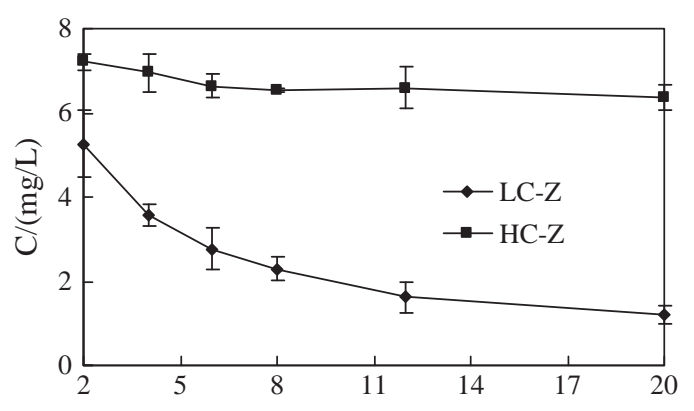

Adsorbent dosage/(g/L)

Fig. 6. Ammonium concentration in wastewater from sewage treatment plant after treatment by $\mathrm{LC}-\mathrm{Z}$ and $\mathrm{HC}-\mathrm{Z}\left(\mathrm{C}_{0}=7.3 \mathrm{mg} / \mathrm{L} ; \mathrm{pH}=8.0 ; \mathrm{T}=25^{\circ} \mathrm{C}\right)$.
Ca-leaching from HC-Z. The ammonium uptake by HC-Z is mainly carried out by the following ion-exchange reaction:

Zeolite-Ca ${ }^{2+}+2 \mathrm{NH}_{4}^{+} \leftrightarrow \mathrm{Ca}^{2+}+$ Zeolite- $2 \mathrm{NH}_{4}^{+}$

As $\mathrm{Ca}^{2+}$ can leach from Ca-compounds present in HC-Z, the ionexchange reaction would be shifted from right to left with the increase of $\mathrm{Ca}^{2+}$ in the solution, resulting to the ammonium uptake reduction.

To remove the leaching $\mathrm{Ca}^{2+}$-ions, the $\mathrm{HC}-\mathrm{Z}$ was washed with distilled water. The previous studies showed that the double charge of $\mathrm{Ca}^{2+}$ makes the exchangewith ammonium more difficult [9]. Therefore, HC-Z was washed with $\mathrm{NaCl}$ solution $(1 \mathrm{~mol} / \mathrm{L})$, which can substitute the exchangeable $\mathrm{Ca}^{2+}$ with $\mathrm{Na}^{+}$in addition to removing the leaching $\mathrm{Ca}^{2+}$-ions. After washing, the two obtained materials were then used to remove ammonium, and the results are given in Table 6 . The results show that the ammonium uptake capacities of the distilled water and $\mathrm{NaCl}$ treated $\mathrm{HC}-\mathrm{Z}$ were 0.88 and $0.97 \mathrm{mg} / \mathrm{g}$, respectively. They were higher than that of the original HC-Z $(0.70 \mathrm{mg} / \mathrm{g})$, while still much less than that of LC-Z $(7.47 \mathrm{mg} / \mathrm{g})$. This indicates that after distilled water and $\mathrm{NaCl}$ washing, the improvement of ammonium uptake of HC-Z is not significant. It is well known that CEC of zeolitic materials is proportional to the concentration of zeolites with cation exchange properties present in the zeolitic material. The higher CEC of LC-Z indicates that the concentration of zeolite in LC-Z is higher than that in HC-Z, which is also confirmed by XRD data (Fig. 3). In the XRD patterns in Fig. 3, the peak intensity of zeolites in LC-Z was higher than that of gismondine in HC-Z. The peak intensity of a mineral is non-linearly proportional to its content in the detected material. It can thus be concluded that the zeolite content in LC-Z is higher than that in HC-Z, which may be the

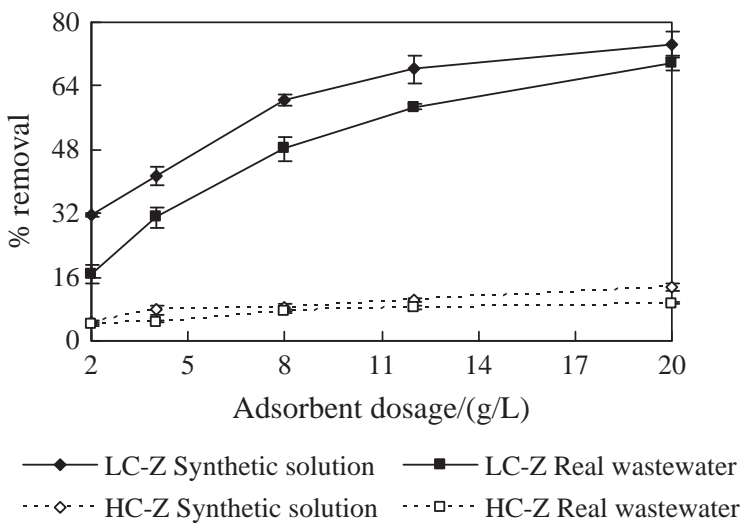

Fig. 7. Ammonium removal efficiency of LC-Z and HC-Z in the synthetic solution and real wastewater $\left(\mathrm{C}_{0}=100 \mathrm{mg} / \mathrm{L} ; \mathrm{pH}=8.0 ; \mathrm{T}=25^{\circ} \mathrm{C}\right)$. 
Table 6

Concentrations of cations in different reaction solution and ammonium uptake capacity of different adsorbents. (adsorbent dose $=4 \mathrm{~g} / \mathrm{L} ; \mathrm{pH}=8.0 ; \mathrm{C}_{0}=50 \mathrm{mg} / \mathrm{L} ; \mathrm{T}=25^{\circ} \mathrm{C}$ ).

\begin{tabular}{|c|c|c|c|c|c|c|}
\hline \multirow{2}{*}{\multicolumn{3}{|c|}{ The reaction solution }} & \multicolumn{4}{|c|}{ Cations concentrations (mg/L) } \\
\hline & & & $\mathrm{Na}^{+}$ & $\mathrm{K}^{+}$ & $\mathrm{Ca}^{2+}$ & $\mathrm{Mg}^{2+}$ \\
\hline \multirow{3}{*}{\multicolumn{3}{|c|}{$\begin{array}{l}\text { The solution treated by LC-Z } \\
\text { The solution treated by HC-Z } \\
\text { The solution obtained by agitating } \\
\text { HC-Z with distilled water }\end{array}$}} & 121.33 & 1.90 & -0.18 & -0.01 \\
\hline & & & 16.51 & 26.8 & 126.07 & 1.57 \\
\hline & & & 16.69 & 2.87 & 92.65 & 1.11 \\
\hline \multicolumn{7}{|c|}{ The ammonium uptake capacity (mg/g) } \\
\hline LC-Z & HC-Z & \multicolumn{3}{|c|}{ Distilled water treated HC-Z } & \multicolumn{2}{|c|}{$\mathrm{NaCl}$ treated $\mathrm{HC}-\mathrm{Z}$} \\
\hline 7.47 & 0.70 & \multicolumn{3}{|l|}{0.88} & \multicolumn{2}{|l|}{0.97} \\
\hline
\end{tabular}

main reason for the lower ammonium uptake capacity of HC-Z than LC-Z. The lower zeolite content of HC-Z may be due to the higher iron and calcium content in it. Fe is usually present in the form of magnetite which could behave as inert material for zeolite synthesis. Through the formation of calcium silicate, Ca-compounds could also act as a zeolite synthesis inhibitor [19]. The higher SSA of HC-Z may be mainly attributed to the formation of rough surface.

The previous studies showed that the type and the yield of synthesized zeoltie depended strongly on the silica-alumina composition of the fly ash source [20]. However, our studies show that the calcium content in starting fly ash should be also considered during the synthesis of the zeolite. Since the main mechanism of phosphate removal by the synthesized zeolite was the formation of calcium phosphate and high-calcium content could favor that process, the high-calcium (Class C) fly ash should be chosen preferentially as the starting material of the zeolite synthesis for phosphate removal. Nevertheless, the main mechanism of ammonium removal by the synthesized zeolite is ion exchange. The existence of calcium in fly ash firstly inhibits the synthesis of zeolite by the formation of calcium silicate. The Ca-compound in the synthesized zeolite can leach $\mathrm{Ca}^{2+}$ into the solution, and the leaching $\mathrm{Ca}^{2+}$ then hinders the ion exchange of ammonium with the exchangeable $\mathrm{Ca}^{2+}$ in the zeolite. Thus, to obtain the synthesized zeolite with high ammonium uptake capacity, as the starting material, the low-calcium (Class F) fly ash is preferable to high-calcium (Class $\mathrm{C}$ ) fly ash. This also shows that the combination of LC-Z and HC-Z may have a high potential for the simultaneous removal of phosphate and ammonium. More studies should still be conducted to investigate the ammonium removal performance of the synthesized zeolite from other fly ash with different chemical compositions, so as to consummate the select criteria of the starting fly ash of the zeolite synthesis for ammonium removal.

\section{Conclusions}

After alkaline fusion followed by hydrothermal treatment, the LC-Z and HC-Z were synthesized from fly ashes, and their main crystals were identified as faujasite and gismondine, respectively. The SSA and CEC increased significantly following the synthesis process. The SSA and CEC of LC-Z were $27.02 \mathrm{~m}^{2} / \mathrm{g}$ and $2.79 \mathrm{meq} / \mathrm{g}$, and those of HC-Z were $45.511 \mathrm{~m}^{2} / \mathrm{g}$ and $0.69 \mathrm{meq} / \mathrm{g}$, respectively. The kinetics of the ammonium uptake on both LC-Z and HC-Z followed the Ho's pseudo-secondorder model. The rate constant was obtained as $3.63 \times 10^{-2}$ for LC-Z and $0.72 \times 10^{-2} \mathrm{~g} \cdot \mathrm{mg}^{-1} \cdot \mathrm{min}^{-1}$ for $\mathrm{HC}-\mathrm{Z}$, respectively. The Langmuir model provided better fit with the equilibrium data of LC-Z, while the Freundlich model gave better fit for HC-Z. The obtained maximum ammonium uptake capacities were $23.8 \mathrm{mg} / \mathrm{g}$ for LC-Z and $3.17 \mathrm{mg} / \mathrm{g}$ for $\mathrm{HC}-\mathrm{Z}$, respectively. At the adsorbent dosage of $20 \mathrm{~g} / \mathrm{L}$, after treatment by $\mathrm{LC}-\mathrm{Z}$, the ammonium concentration in the effluent from a sewage treatment plant basically met Surface Water Environment Quality Standard in China (GB3838-2002) IV, whereas the standard could not be met in the effluent treated by HC-Z. The $\mathrm{Ca}^{2+}$ leaching and the lower zeolite content in HC-Z are the main factors for its lower ammonium uptake capacity. So, to obtain the synthesized zeolite with high ammonium removal capacity, the low-calcium (Class F) fly ash rather than the high-calcium (Class C) fly ash should be chosen preferentially as the raw material of the zeolite synthesis.

\section{Acknowledgements}

This work was supported by the National Water Special Project (2009ZX07210-009-02), the National Science and Technology Support Project (2006BAC10B03) and the National High Technology R\&D Program (2008AA06Z301).

\section{References}

[1] H. Paerl, Doing battle with the green monster of Taihu Lake, Science 317 (2007) 1166.

[2] M. Yang, J.W. Yu, Z.H. Li, Z.H. Guo, M. Burch, T.F. Lin, Taihu Lake not to blame for Wuxi's woes, Science 319 (2008) 158.

[3] L.C. Lei, X.J. Li, X.W. Zhang, Ammonium removal from aqueous solutions using microwave-treated natural Chinese zeolite, Separation and Purification Technology 58 (2008) 359-366.

[4] H.M. Baker, H. Fraij, Principles of interaction of ammonium ion with natural Jordanian deposits: analysis of uptake studies, Desalination 251 (2010) 41-46.

[5] D. Karadag, Y. Koc, M. Turan, B. Armagan, Removal of ammonium ion from aqueous solution using natural Turkish clinoptilolite, Journal of Hazardous Material 136 (2006) 604-609.

[6] M. Ahmaruzzaman, A review on the utilization of fly ash, Progress in Energy and Combustion Science 36 (2010) 327-363.

[7] X. Querol, N. Moreno, J.C. Umaña, A. Alastuey, E. Hernández, A. López-Soler, F. Plana, Synthesis of zeolites from coal fly ash: an overview, International Journal of Coal Geology 50 (2002) 413-423.

[8] M.L. Zhang, H.Y. Zhang, D. Xu, L. Han, D.X. Niu, B.H. Tian, J. Zhang, L.Y. Zhang, W.S. $\mathrm{Wu}$, Removal of ammonium from aqueous solutions using zeolite synthesized from fly ash by a fusion method, Desalination 271 (2011) 111-121.

[9] R. Juan, S. Hernández, J.M. Andrés, C. Ruiz, Ion exchange uptake of ammonium in wastewater from a sewage treatment plant by zeolitic materials from fly ash, Journal of Hazardous Materials 161 (2-3) (2009) 781-786.

[10] S.V.Vassilev, C.G. Vassileva, A new approach for the classification of coal fly ashes based on their origin, composition, properties, and behaviour, Fuel 86 (2007) 1490-1512.

[11] S. Lagergren, About the theory of so-called adsorption of soluble substances, Kung Sven Veten Hand 24 (1898) 1-39.

[12] Y.S. Ho, G. McKay, Pseudo-second order model for sorption processes, Process Biochemistry 34 (1999) 451-465.

[13] I. Langmuir, The adsorption of gases on plane surfaces of glass, mica and platinum, Journal of the American Chemical Society 40 (1918) 1361-1367.

[14] H.M.F. Freundlic, Uber die adsorption in losungen, Zeitschrift für Physikalische Chemie (Leipzig) 57A (1906).

[15] K.R. Hall, L.C. Eagleton, A. Acrivos, T. Vermeulen, Pore and solid diffusion kinetics in fixed bed adsorption under constant pattern conditions, Industrial and Engineering Chemistry Fundamentals 5 (1966) 212-219.

[16] A. Thornton, P. Pearce, S.A. Parsons, Ammonium removal from solution using ion exchange on to MesoLite, an equilibrium study, Journal of Hazardous Materials 147 (3) (2007) 883-889.

[17] A.M. Yusof, L.K. Keat, Z. Ibrahim, Z.A. Majid, N.A. Nizam, Kinetic and equilibrium studies of the removal of ammonium ions from aqueous solution by rice husk ashsynthesized zeolite $\mathrm{Y}$ and powdered and granulated forms of mordenite, Journal of Hazardous Materials 174 (2010) 380-385.

[18] D. Karadag, Y. Koc, M. Turan, M. Ozturk, A comparative study of linear and nonlinear regression analysis for ammonium exchange by clinoptilolite zeolite, Journal of Hazardous Materials 144 (2007) 432-437.

[19] R. Juan, S. Hernández, J.M. Andrés, C. Ruiz, Synthesis granular zeolitic materials with high cation exchange capacity from agglomerated coal fly ash, Fuel 86 (2007) 1811-1821.

[20] M. Inada, Y. Eguchi, N. Enomoto, J. Hojo, Synthesis of zeolite from coal fly ashes with different silica-alumina composition, Fuel 84 (2005) 299-304.

[21] D.Y. Wu, B.H. Zhang, C.J. Li, Z.J. Zhang, H.N. Kong, Simultaneous removal of ammonium and phosphate by zeolite synthesized from fly ash as influenced by salt treatment, Journal of Colloid and Interface Science 304 (2006) 300-306.

[22] A. Demir, A. Gunay, E. Debik, Ammonium removal from aqueous solution by ion exchange using packed bed natural zeolite, Water SA 28 (3) (2002) 329-336.

[23] L.R. Weatherley, N.D. Miladinovic, Comparison of the ion exchange uptake of ammonium ion onto New Zealand clinoptilolite and mordenite, Water Research 38 (20) (2004) 4305-4312.

[24] Q. Du, S.J. Liu, Z.H. Cao, Y.Q. Wang, Ammonia removal from aqueous solution using natural Chinese clinoptilolite, Separation and Purification Technology 44 (3) (2005) 229-234.

[25] O. Lahav, M. Green, Ammonium removal using ion exchange and biological regeneration, Water Research 32 (7) (1998) 2019-2028.

[26] M. Sarioglu, Removal of ammonium from municipal wastewater using natural Turkish (Dogantepe) zeolite, Separation and Purification Technology 41 (1) (2005) 1-11. 